\title{
DIAGNOSIS OF THE IMPACT OF THE GABČÍKOVO WATER PROJECT ON SOIL WATER REGIME IN THE SURROUNDINGS
}

\author{
Miroslava JARABICOVÁ, Mária PÁSZTOROVÁ, Justína VITKOVÁ, Peter MINARIČ* \\ Slovak University of Technology in Bratislava, Slovak Republic
}

\begin{abstract}
Rye Island is a unique natural formation, which lies between the main flow of the Danube River and the Little Danube River and is the largest river island in Europe. It is located in the southwest of Slovakia and with its mild to slightly warm climate is one of the most fertile agricultural areas in Slovakia. The whole Rye Island is also our greatest reservoir of quality waters used for drinking purposes, where groundwaters of Rye Island are permanently supplied with water from the Danube River. It means that as water levels in the Danube River were unstable before the construction of the Gabčíkovo Water Project, also the groundwater level faced large fluctuations. Changes occurred after putting the Gabčíkovo Water Project into service, with a decrease in groundwater levels. Thereby, the conditions for agriculture have improved and drying of surrounding protected floodplain forests has stopped. Through the present contribution we decided to analyse the impact of Gabčíkovo on soil water regime in the area of Rye Island, and evaluate the course of groundwater level, precipitation and soil water storage over time. For the representative area we chose a forest ecosystem of Královská Lúka and evaluated the period 1999 to 2009.
\end{abstract}

Keywords: the Gabčíkovo Water Project, soil water regime, groundwater level, precipitation, soil water storage

Soil water regime (SWR) is the result of natural processes of water movement and it is the most important soil regime, which significantly affects the soil production capacity. The SWR is influenced by various factors such as location of soil sites in topography, hydrophysical properties of soil, groundwater, climate conditions, vegetation, and most significantly by human impact. An example of this anthropogenic impact is the construction of the Gabčíkovo Water Project on important lowland, which is agriculturally used and is an area with the richest reserves of drinking water in Slovakia - Rye Island. The groundwater storages of Rye Island are permanently supplied with water from the Danube River. The water levels of the Danube River were unstable before the construction of the Gabčíkovo Water Project, therefore relatively large fluctuations could also be observed in the groundwater levels of the area. The change occurred after the Gabčíkovo Water Project was put into service, with the drop in the groundwater levels, thereby improving the conditions for agriculture and surrounding protected floodplain forests. Therefore, we decided to analyse the impact of the construction of the Gabčíkovo Water Project on the soil water regime in the area of Rye Island.

\section{Material and methods}

The Rye Island (Figure 1) is located in the south western part of Slovakia, near the border with Hungary. It is a separate geographic unit, where the natural boundaries are formed by the Danube riverbed in the south, by the branch of the Little Danube River in the north, and a short part of the Váh River (Vážsky Dunaj) from the east. The locality with the total area of $1,885 \mathrm{~km}^{2}$ is mainly flat and has an elliptical shape. Its length is $84 \mathrm{~km}$, and width ranges from 15 to $30 \mathrm{~km}$. The highest point is located near the town of Šamorín (134 m above sea level) and the lowest area is in the proximity of Komárno (105 $\mathrm{m}$ above sea level). This small slope was created by the gradual deposition of smaller deposits of gravel, sand and sludge flood.

Geologically, the area consists of quaternary alluvial sediments from Pleistocene and Holocene. The main part of the Rye Island consists of sandy sediments, which are in the tectonically subsiding central part up to $300 \mathrm{~m}$ thick. Young Holocene sediments can be found in the middle and lower part of Rye Island, and mainly in the areas close to the rivers of Danube and Little Danube.

Gravel underlay is situated from 50 or $70 \mathrm{~cm}$ below the surface (in the middle and mainly the upper part of the Rye Island) to 6 or $8 \mathrm{~m}$ (mostly in the lower part of the Rye Island). The depth of this interface is characterised by a large inhomogeneity in the area of Rye Island. Gravel and sand gravel sediments are covered by a younger loam or loamy sand alluvial sludge sediments, less by sandy clays and clays. The border between gravel layer and the surface layer has an important role in the water cycle of Rye Island's natural environment and in the groundwater hydrology of this region (Mucha et al., 1992, 1993; Mucha, 1995; Kosorin, 1997; 1998; Burger, 1979; 1999; Burger, Čelková, 1992; Pospíšil et al., 1979; 2000).

Rye Island is the warmest and also the driest area of Slovakia. It belongs to regions with warm climate, typically warm and dry with mild winter and with longer duration of sunshine. The average annual temperature in Hurbanovo is $10.3^{\circ} \mathrm{C}$ and the average temperature in summer is $16.7^{\circ} \mathrm{C}$. The average annual precipitation in Hurbanovo is $523 \mathrm{~mm}$ and the average precipitation for the summer period is $303 \mathrm{~mm}$. The highest precipitations are in the months of June and July and the lowest precipitation is in the first three months of the year.

The most important area of Rye Island is the forest ecosystems of floodplain forests in the area between the 


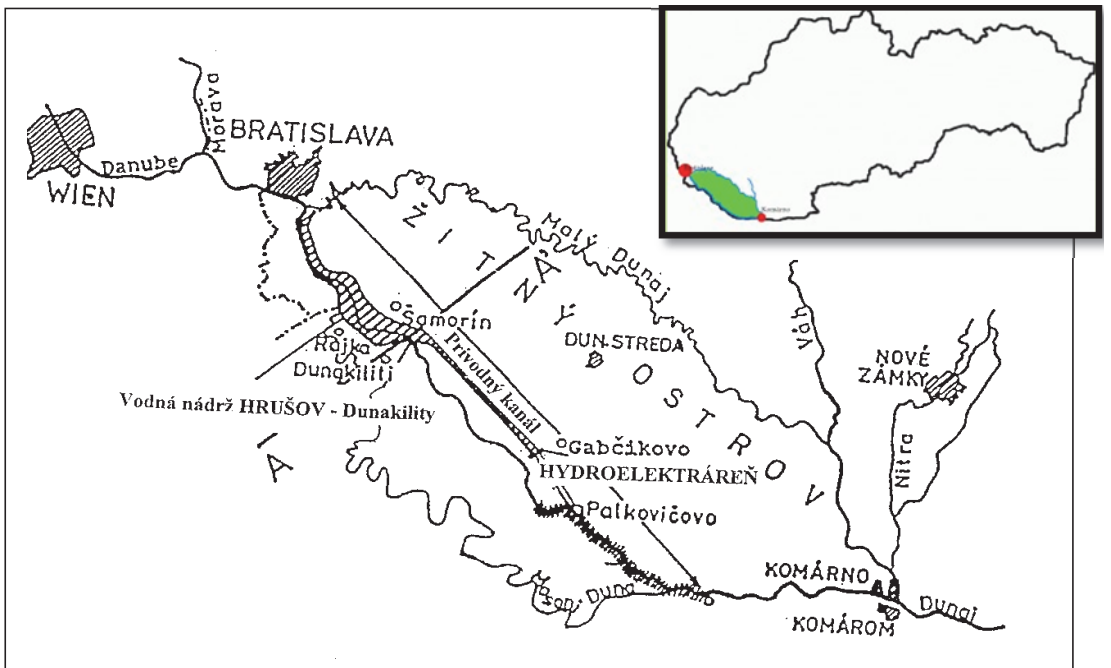

Figure 1 Location of Rye Island within Slovakia and its schematic definition

old Danube riverbed and the inlet canal. The aim of hydrologists and environmentalists is to arrange the stability of optimal water storage of this area in relation with optimal water supply of the area. Therefore, it is important to make image about the SWR in the floodplain forest area.

The Institute of Hydrology, Slovak Academy of Sciences, in its research activities monitors the depths of groundwater levels (GWL) in the area of interest (Královská lúka). The monitoring is still ongoing from the year 1999 with a frequency of two weeks during the growing season and approximately once a month during winter.

The groundwater of Rye Island is permanently supplied with water from the Danube River. The infiltrated water flows through highly permeable gravel in the south-eastern direction, approximately parallel with the Danube. The GWL during the year, before the Gabčíkovo Water Project was put into service, demonstrated relatively large fluctuation. In the longterm average, the GWL fluctuated in the range of 4-7 $\mathrm{m}$ below the surface in the upper part, 2-4 $\mathrm{m}$ in the middle part (up to Dunajská Streda) and 0-2 m in the lower part of the Rye Island and in depressions (Porubský et al., 1971; Kalnová, 1976). The decrease of GWL stopped after the Gabčíkovo Water Project was put into service.

A forest ecosystem Královská lúka, where land is not cultivated throughout the year, was selected as a representative site (Šútor and Štekauerová, 2000). The soil profile of the area has the following structure: 0-30 $\mathrm{cm}$ below the surface - sandy loam, 30-40 cm - loam, 55-90 cm sandy loam and in the depth in the range of 105-115 cm - sand (Šútor and Štekauerová, 2000; Mudráková, 2011). The gravel layer begins at approximately $250 \mathrm{~cm}$ below the surface, and the GWL in the year 1996 was in the depths of $150 \mathrm{~cm}$ to $241 \mathrm{~cm}$ below the surface, with mean value of $191 \mathrm{~cm}$.

\section{Results and discussion}

\section{Development of soil water storage} within the Kral'ovská lúka site

To establish and assess the soil water storage (SWS) in the forest ecosystem of Královská lúka, the soil moisture was monitored by neutron probe by the Institute of Hydrology in the years 1999-2002 (it is still monitored). The monitored soil moisture was further

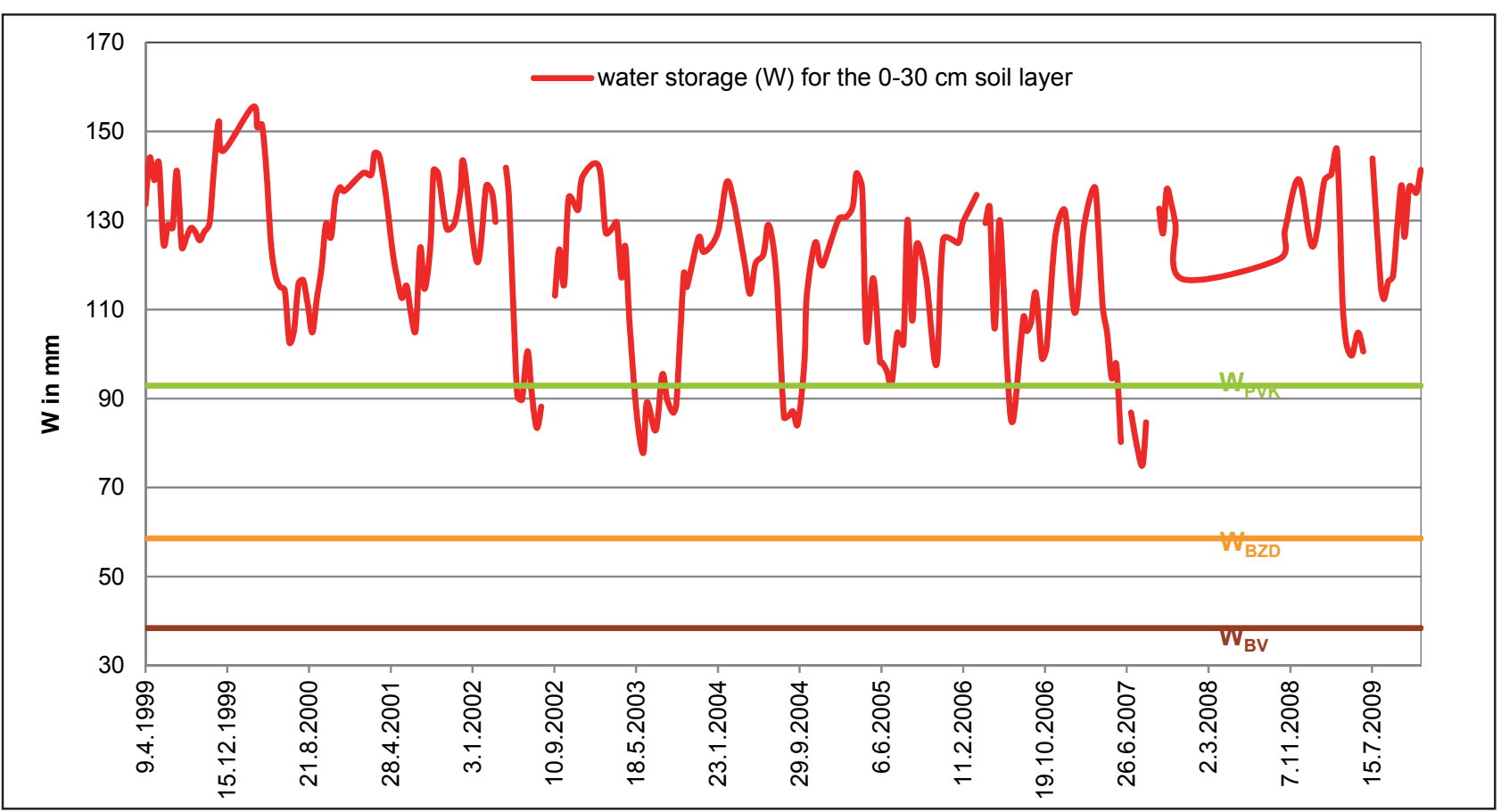

Figure 2 Comparison of actual water storage $(W)$ for the $0-30 \mathrm{~cm}$ soil layer with water storage calculated for hydrolimits $\mathrm{W}_{\mathrm{PVK}}$ $W_{B Z D}$ and $W_{B V}$ in the area of Královská lúka during the years 1999-2009 
used to calculate the soil water storage in the predefined soil layers: $0-30 \mathrm{~cm}, 0-50 \mathrm{~cm}, 50-100 \mathrm{~cm}$ and $0-100 \mathrm{~cm}$ below the ground. In this paper, however, we will pay closer attention to the soil layer which is $0-30 \mathrm{~cm}$ below the ground. The soil water storage was analysed with respect to the soil moisture characteristics from the perspective of plants (hydrolimits).

Because the changes in the soil water regime are affected mainly by the GWL and precipitation, in addition to the development of soil water storage we also included the impact of groundwater levels and precipitation on SWS.

Comparison of actual SWS for the soil layer $0-30 \mathrm{~cm}$ below the surface with SWS calculated for hydrolimits of field capacity $\left(\mathrm{W}_{\mathrm{PVK}}\right)$, point of decreased availability $\left(\mathrm{W}_{\mathrm{BZD}}\right)$ and wilting point $\left(\mathrm{W}_{\mathrm{BV}}\right)$ is shown in Figure 2. Since the beginning of the evaluated period until the spring of 2002 , the SWS was always above the $\mathrm{W}_{\mathrm{PVK}}$. During the summer period in 2002, 2003, 2004, 2006 and 2007, this value decreased slightly below $\mathrm{W}_{\mathrm{PVK}}$. In other evaluated periods, the SWS was above WPVK value, thus we can say that the soil layer is sufficiently supplied with water, and in most of the evaluated period the SWS in the evaluated soil layer showed excess of water.

\section{Impact of groundwater level on soil water storage}

The course of the soil water storage in the $0-30 \mathrm{~cm}$ layer below the surface and the groundwater levels (GWL) in the days of measurement for the period of 1999-2009 are shown in Figure 3. The largest soil water storages were recorded in the winter (maximum March $2000-155.5 \mathrm{~mm}$ ). On 26 March 2002, 15 August 2002, 27 August 2002, 6 April 2006, 22 June 2007, 11 September 2007 and 3 July 2009, the area was flooded, which means that the water was on

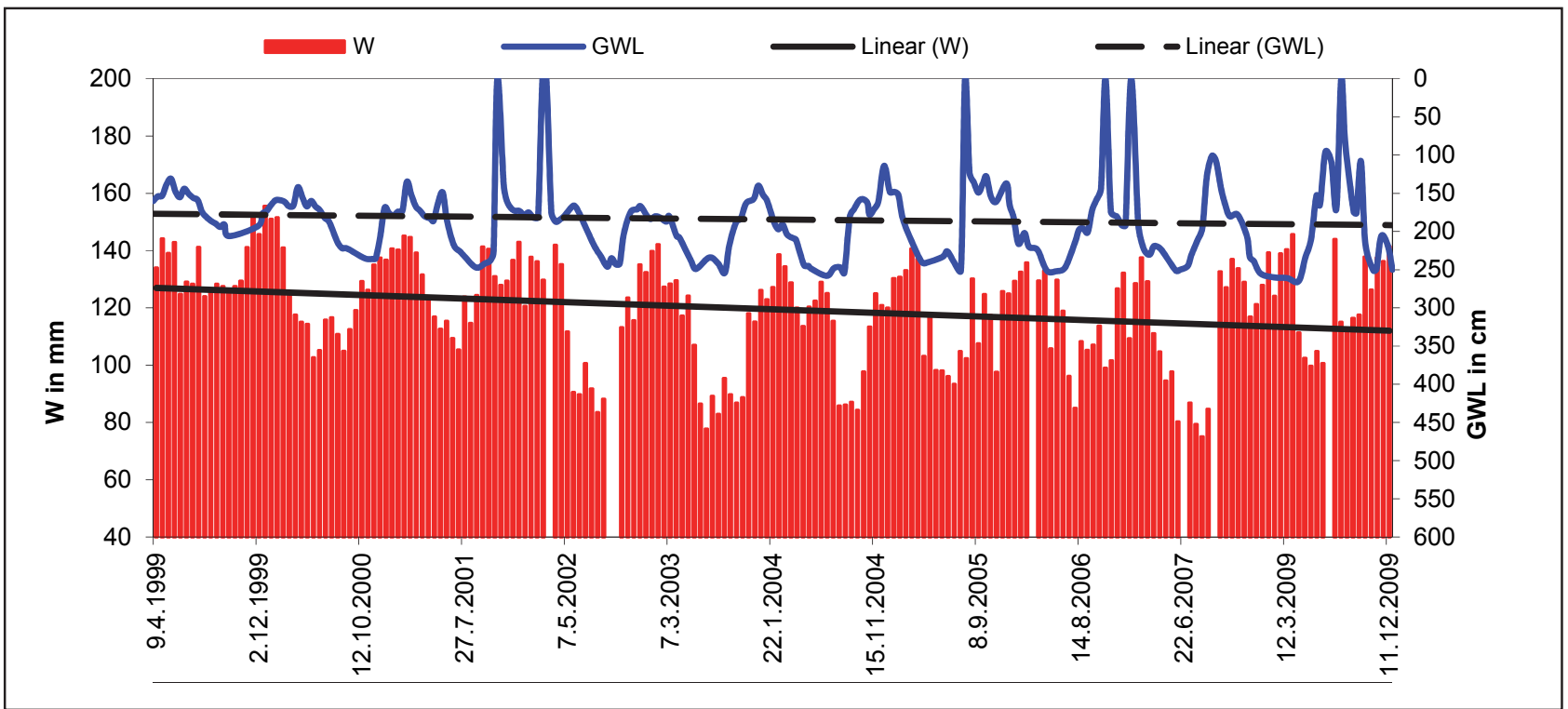

Figure 3 Course of actual water storage (W) for the $0-30 \mathrm{~cm}$ soil layer and course of groundwater level (GWL) in the area of Královská lúka during the years 1999-2009

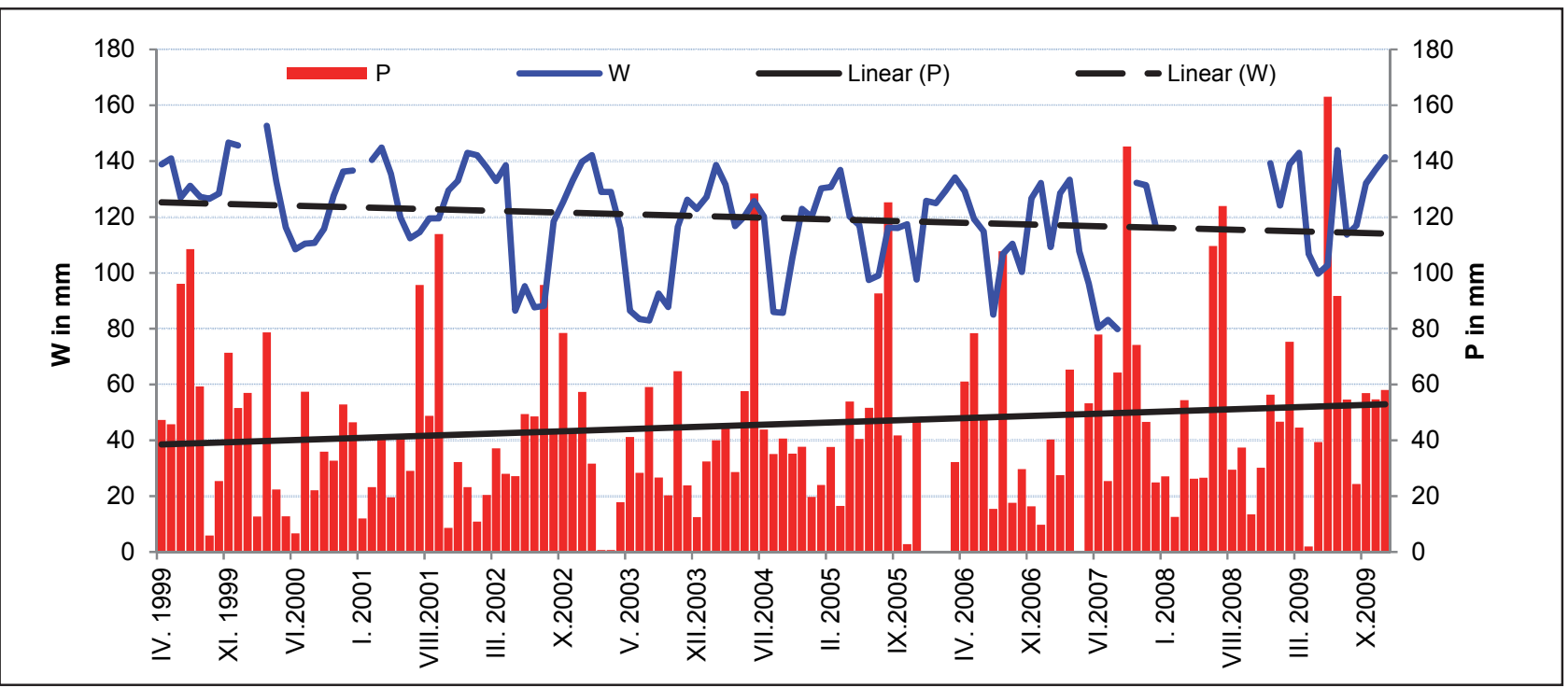

Figure 4 Course of average monthly water storage (W) in the soil layer 0-30 cm and course of monthly precipitation totals (P) in the area of Král'ovská lúka during the period 1999-2009 
the ground surface. Therefore, the measurements were not realized. The lowest values of SWS were during the summer months (minimum August $2007-75 \mathrm{~mm}$ ).

The course of GWL fluctuates in the range of $86-265 \mathrm{~cm}$ below the surface throughout the whole evaluated period of 1999-2009 (Figure 3). During this period, smaller and larger decreases were observed (mostly in summer) and then increases (in winter) are more significant. In the 1st quarter of 2009, the GWL reached the lowest level - 265 $\mathrm{cm}$ below the surface for the period of 1999-2009, which was likely caused by the deficit of precipitation during this period. In the summer of 2009, the GWL increased to the ground surface due to intense precipitation.

In Figure 3 there is the trend of SWS in the soil layer 0-30 $\mathrm{cm}$ and the GWL in the area of Královská lúka for the period of 1999-2009, where we can see a slightly decreasing trend of both elements.

\section{Impact of precipitation on soil water storage}

The course of the average monthly soil water storage (W) in the soil layer $0-30 \mathrm{~cm}$ below the surface and monthly precipitation totals (P) for the period of 1999-2009 are shown in Figure 4. The trend lines illustrating the growing trend of precipitation and vice versa, the decreasing trend in soil water storage (W) are also shown. The achieved results may be distorted by the missing measurements of soil moisture during the period from 13 December 2007 to 10 January 2008 (only 3 measurements), when high monthly precipitation values were observed (June 2008 - $109.6 \mathrm{~mm}$, August 2008 - $123.9 \mathrm{~mm}$ ).

\section{Conclusion}

Due to the changes that have occurred in the territory of Rye Island, we decided to analyse the impact of the Gabčíkovo Water Project on the soil water regime through the soil water storage of the representative forest ecosystem of Královská lúka for the period of 1999-2009.

Based on the analysis results, it can be concluded that the forest ecosystem has a sufficient soil water storage, because its value did not decrease below the wilting point in the soil layer $0-30 \mathrm{~cm}$ below the surface. In the main part of the reporting period, the soil water storage ranged above the field capacity, thus the soil layer is sufficiently supplied with water; we can even say that there is excess water. Despite the fact that the SWS and the GWL have a slightly decreasing trend for the period of 1999-2000, there is no shortage of water for vegetation.

In the analysis of the soil water storage, we also evaluated the impact of GWL and precipitation on the soil water storage. We concluded that the groundwater level has a greater influence on the course of soil water storage than precipitation. However, the results can be obviously distorted, because in periods of high monthly precipitation totals (June 2008 - $109.6 \mathrm{~mm}$, August 2008 - $123.9 \mathrm{~mm}$ ), the soil moisture measurements were conducted only three times.

In conclusion, the putting of the Gabčíkovo Water Project into service has a positive impact on the level regime of Rye Island, which subsequently had a positive impact on the soil water regime of the area. It means that the studied forest ecosystem of Král'ovská lúka has not been deficient of
SWS, but the locality is sufficiently supplied with water and in most of the evaluated period there is even excess water in soil.

\section{Acknowledgement:}

We are grateful for the support from the following projects APVV-0139-10, VEGA 1/0243/11, VEGA 1/1044/11 and VEGA 2/0040/12.

\section{References}

BURGER, F. 1979. Stanovenie základných hydrofyzikálnych charakteristík pórovitého prostredia $v$ teréne. In Vodohospodársky časopis, roč. 27, č. 1, 1979. s.107-122.

BURGER, F. 1999. Klasifikácia modelov reakcie režimu podpovrchových vôd na antropogénnu činnost'. In: Zborník z III. vedeckej konferencie s medzinárodnou účastou "Vplyv antropogénnej činnosti na vodný režim nížinného územia", ÚH SAV, Michalovce, Zemplínska Šírava. 1999. s. 262-267.

BURGER, F. - ČELKOVÁ, A. 1992. Výskyt mineralizovanej podzemnej vody v okolí VD Gabčíkovo a jej vplyv na salinizáciu pôdy. In: Zborník z konferencie SvF VUT Brno. 1992. s. 249-253.

KOSORIN, K. 1997. Priestorová dynamika podzemných vôd Žitného ostrova. In Vodohospodársky časopis, roč. 45, 1997. s. 348-364.

KOSORIN, K. 1998. Hydraulické zásady a výpočtové prostriedky optimalizácie hladinového a prietokového režimu ovládaných kanálových sústav nížinných oblastí. Bratislava : ÚH SAV, 1998.

MUDRÁKOVÁ, J. 2011. Diagnostika vodného režimu polnohospodárskych a lesných ekosystémov. Diplomová práca, Bratislava : STU, 2011.

MUCHA, I. a i. 1992. Danubian Lowland - Groundwater Model 1. PHARE Project No. PHARE/EC/WAT/1, Workshop in Bratislava, June 10-13, 1992.

MUCHA, I. - PAULÍKOVÁ, E. - HLAVATÝ, Z. - RODÁK, D. - ZELINA, I. 1993. Optimisation of the completion of Hydroelectric power structures Gabčikovo within the area of ČSFR from the point of view of impacts on the groundwater. Groundwater Consulting. Bratislava : Comenius University, 1993.

MUCHA, I. 1995. The Gabčíkovo Part of the Hydroelectric Power Project. Gabčíkovo - Nagymaros Enviromental impact Review. In: Gabčikovo Part of the Hydroelectric Power Project - Enviromental Impact Review. Bratislava : Comenius University, 1995. pp.315-322. PORUBSKÝ, A. 1971. Vodné bohatstvo Slovenska. Bratislava : VEDA, Vydavatel'stvo SAV, 1971.319 s.

POSPIŚIL,P.-VASS, D. - MELIORIS, L. - REPKA,T. 1979: Neotektonická stavba Žitného ostrova a prilahlého územia Podunajskej nížiny. In Minerália Slovaca, roč. 10, 1979. s. 443-456.

POSPÍŠIL, P. - BODIŠ, D. - KOVACS, T. - LEŠKO, A. 2000. Vplyv anizotropného prostredia na prúdenie podzemnej vody, jej kvalitu a ochranu. In Podzemná voda, roč. 6, č. 2, 2000. s. 210-223.

ŠÚTOR, J. - ŠTEKAUEROVÁ, V. 2000: Hydrofyzikálne charakteristiky pôd Žitného ostrova. Bratislava : ÚH SAV, 2000. 163 s. ISBN 80-968480-1-1.

\section{Contact address:}

Mgr. Peter Minarič, Slovak University of Technology in Bratislava, Faculty of Civil Engineering, Department of Land and Water Resources Management, Radlinského 11, 813 68 Bratislava, Slovakia, phone +421 0259274 616, e-mail: peter.minaric@stuba.sk 